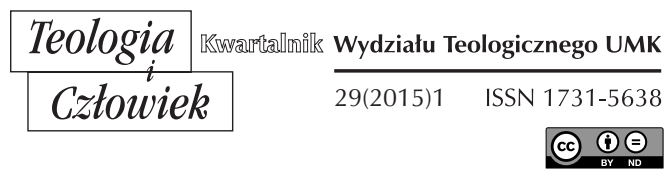

MICHAŁ WOJCIECHOWSKI*

OLSZTYN

\title{
AJSCHYLOS, SOFOKLES, EURYPIDES RELIGIJNOŚĆ TRZECH TRAGIKÓW GRECKICH
}

DOI: http://dx.doi.org/10.12775/TiCz.2015.009

Trzej ateńscy poeci, Ajschylos, Sofokles i Eurypides, położyli w V wieku przed Chr. fundament pod sztukę teatralną ${ }^{1}$. Po pierwsze, stworzyli dramat jako gatunek, poetyckie przedstawienie $\mathrm{z}$ aktorami i urozmaiconą akcją ${ }^{2}$. Nowa forma okazała się nadzwyczaj bogata w moż-

* Michał Wojciechowski, teolog świecki, biblista, profesor na Wydziale Teologii Uniwersytetu Warmińsko-Mazurskiego

${ }^{1}$ O tych autorach zob. zwł. Literatura Grecji starożytnej, red. H. Podbielski, t. 1-2, Lublin 2, t. 1; wcześniej T. Sinko, Zarys historii literatury greckiej, 2 t., Warszawa 1959; krócej M. Cytowska, H. Szelest, Historia literatury starożytnej, wyd. 4, Warszawa 2006; popularnie Z. Kubiak, Literatura Greków i Rzymian, Warszawa 1999. Encyklopedie: Neue Pauly. Enzyklopädie der Antike, t. 1-16, Stuttgart 1996-2003; ang. Brill's New Pauly. Encyclopaedia of the Ancient World, Leiden 2006; Der kleine Pauly. Lexikon der Antike, t. 1-5, Stuttgart 1964.

2 Zob. ogólnie (z rozdziałami o tematyce religijnej): J. de Romilly, Tragedia grecka, Warszawa 1994; O. Taplin, Tragedia grecka w działaniu, Kraków 2004; M. McDonald, J.M. Walton (red.), The Cambridge Companion to Greek and Roman Theatre, Cambridge 2007; J. Gregory (red.), A Companion to Greek Tragedy, London 2005; N.S. Rabinowitz, 
liwości, nawet przy zachowaniu zasady jedności miejsca i czasu akcji, zresztą od początku nie zawsze stosowanej. Wpłynęła też na gatunki pokrewne tragedii, od komedii po operę (sztuki greckie wystawiano z muzyką, niestety utraconą).

Po drugie, w ramach swoich sztuk pokazali w sposób wyjątkowo pełny los ludzki, namiętności i cierpienia. Człowiek w dramacie spotyka siebie, innych, przeznaczenie i bogów. Tłem dramatów jest religia grecka jako całość ${ }^{3}$. Religijność i niepokój religijny są ważnym składnikiem przesłania wielkich tragików. Można ich śmiało nazwać teologami, w tym sensie, że starali się wniknąć w tajemnicę boskości. Zresztą wystawianie tragedii samo było w Atenach składnikiem kultu, święta na cześć Dionizosa, a więc można je rozumieć jako religijne oświetlenie dramatycznych zdarzeń i emocji.

$\mathrm{Na}$ pytania religijne odpowiadają ci tragicy w sposób rozmaity: logiczny Ajschylos wierzy w przeznaczenie i odpłatę, pobożny Sofokles ufa wyroczniom i boskiemu prawu, niespokojny Eurypides stawia pytanie o zło w świecie. Wszyscy skupiają się na osobowej i moralnej stronie religii, a nie na obrzędowej i społecznej ${ }^{4}$. Wszyscy włączają do swych sztuk modlitwy ${ }^{5}$.

Greek Tragedy, London 200; por. A.J. Festugière, De l'essence de la tragédie grecque, Paris 1969.

${ }^{3} \mathrm{Na}$ jej temat np. W. Lengauer, Religijność starożytnych Greków, Warszawa; M.P. Nilsson, Geschichte der griechischen Religion, t. 1, München 1955; W. Burkert, Greek Religion, Oxford 1985 (niem. 1977); uzupełnił J.A. Bremmer, Greek Religion, Oxford 1994; dawniej T. Zieliński, Religia starożytnej Grecji. Religia hellenizmu, Wrocław 1991; U. von Wilamowitz-Moellendorff, Der Glaube der Hellenen, 2 t., Berlin 1931-1932; W.F. Otto, Theophania. Der Geist der altgriechischen Religion, Hamburg 1956.

${ }^{4}$ Aczkolwiek składanie ofiar ma spore znaczenie dla akcji i język kultu jest szeroko stosowany. Por. W. Burkert, Greek Tragedy and Sacrificial Ritual, Greek, Roman and Byzantine Studies 7(1966), 87-121; K. Bielawski, Terminy rytualno-kultowe $w$ tragedii greckiej epoki klasycznej, Prace Komisji Filologii Klasycznej 32, Kraków 2004.

${ }^{5}$ H. Wójtowicz, Modlitwa $w$ tragedii greckiej, Studia Sandomierskie 1(1980), 333-338; por. antologia gr.-franc. i komentarze: Corpus de prières grecques et romaines, opr. F. Chapot, B. Laurot, t. 1-2, Turnhout 2001. 


\section{AJSCHYLOS:6 FATUM, ETYKA, ZEUS}

Grecki pogląd na świat zakładał przeznaczenie. Mimo swej potęgi i nieśmiertelności także bogowie od niego zależą, gdyż stanowią część podległego mu świata. Przewagę ma więc ten, kto zna przeznaczenie; nieśmiertelny Prometeusz cierpi przykuty do skały, ale wie, że zostanie uwolniony. Wie też, że kiedyś Zeus sam poprosi go o pomoc. Niech sobie tymczasem porządzi! (Prometeusz w okowach 948-950). Słuszną jest rzeczą poddać się przeznaczeniu: w Siedmiu przeciw Tebom Eteokles ostatecznie wychodzi walczyć przeciw zbuntowanemu i zdradzieckiemu bratu i ginie wraz z nim, ocalając swoje miasto.

Dla śmiertelnika wiedza o przyszłości jest jednak ciężarem, dlatego Prometeusz niechętnie godzi się odsłonić zmienionej w jałówkę i gnanej szałem Io jej przyszłe, jeszcze gorsze cierpienia. Jednym z jego darów dla ludzkości okazuje się pozbawienie ludzi wiedzy o sprawach przyszłych! W zamian za to dostali nadzieję, która tym samym jawi się jako złudne pocieszenie (Prometeusz 257-259). Prometeusz występuje jako stwórca, gdyż w mitach pełni on nieraz taką funkcję, zamiast Zeusa.

Taki determinizm losu, stojący za decyzjami bohaterów, choć je sami podejmują, pcha do zbrodni i zemsty postacie z Ajschylosowej trylogii Oresteja, na którą składają się Agamemnon, Ofiarnice i Eumenidy. W łańcuchu zła kryje się jednak logika moralna. I póki Zeus włada w niebie, póty ma to prawo trwać: „Wycierp, coś uczynił” (Agamemnon 1560-1561) 7 .

6 Por. A. Bonnard, La pensée religieuse d'Eschyle, Revue de Teologie et de Philosophie 21(1933), 192-221; W. Kiefner, Der religiöse Allbegriff des Aischylos, Olms 1965; K. Reinhardt, Aeschylos als Regisseur und Theologe, Bern 1949; A. Wartelle, La pensée théologique d'Eschyle, Bulletin de l’Association Guillaume Budé 30(1971), 335-380 (dość kompletnie, autor zauważa, że już ponad sto studiów poświęcili badacze religijności Ajschylosa - temat tego artykułu nadawałby się na dużą monografię, choć ma sens podjąć go też przeglądowo i syntetycznie).

7 Przełożył Stefan Srebrny. Klasyczne dramaty greckie przekładano na polski wielokrotnie. Z wcześniejszych wyróżniają się tłumaczenia Zygmunta Węclewskiego i Jana Kasprowicza. Ostatnio wznawiane były zwłaszcza przekłady Kazimierza Morawskiego i Stefana Srebrnego, a nowszy przekład całego Eurypidesa dał Jerzy Łanowski; te zwykle cytuję (zob. bibliografia: Ajschylos; Sofokles; Eurypides; także Ajschylos, Sofokles, Eurypides, Antologia tragedii greckiej, Kraków 1975). Teksty greckie w wydaniach Loeb Classical Library. 
Cierpienie jest zasłużoną karą, a jako takie pomaga odkupić winę i może uczynić człowieka lepszym. Zbrodnia wymaga jednak odpłaty, choćby w postaci nowej zbrodni. Potrzebę pomsty rozważają obszernie Ofiarnice. Problemem może być przy tym dla Greka tylko to, że kara ma charakter nie indywidualny, lecz zbiorowy, jak kara na całą Troję za stanięcie po stronie wszetecznicy Heleny, albo to, że jest zbyt surowa.

Tę logikę odpłaty ilustruje bliżej mit o dynastii Atrydów. Atreusz na uczcie podał bratu Tyestesowi ciała jego zamordowanych synków, ściągając klątwę na swój ród. Jego syn, król Agamemnon, dla osiągnięcia zwycięstwa na wyprawie wojennej złożył w okropnej, krwawej ofierze własną córkę, a pod Troją, z dala od żony, żył z brankami. Jego żona Klytajmestra wzięła zatem na kochanka ocalałego syna Tyestesa, Ajgista, i zabiła Agamemnona, gdy tylko powrócił.

Zbrodniarze karzą więc zbrodniarzy. Klytajmestra spełniła jednak wolę Zeusa, pchał ją boski duch, siła nadludzka. Miała też argumenty: śmierć córki i zdradę męża. Ale z kolei Agamemnona pomścił krwawo jego syn, Orestes, zgodnie z najwyższą wolą Zeusa i wyrocznią Apollona: jego wieszczba kazała na ten czyn się ważyć (Ofiarnice 272, por. 383-384). Zabił Ajgista i matkę. Na różne sposoby opowiadali o tym dramaturdzy, aż po Szekspira, którego Hamlet naśladuje przecież Orestesa.

Ludzie nie mieli tu wyboru. Jedynie bóg najpotężniejszy, Zeus, może robić, co chce. Oprócz Zeusa nikt nie jest na tym świecie wolny (Prometeusz w okowach 50). Prometeusz zarzuca mu, że zły czyni z tego użytek, bo jest twardy, okrutny, że praw nie chce znać, krom swej woli, nijakich (195-196). Jest tyranem wobec bogów i ludzi. Potwierdza to historia Prometeusza, który cierpi męki za to, że wspomógł ludzi, wykradłszy bogom ogień, a także ucząc ich wszelkiej wiedzy i sztuk. Potwierdza to również historia Io, która padła ofiarą zachcianki Zeusa i zemsty Hery.

Nie oznacza to jednak ataku poety na bogów. Ateńscy widzowie przedstawień, związanych przecież z religijnymi uroczystościami na cześć Dionizosa, nie dopatrzyli się u wielkich tragików bezbożności. Dla Greków bogowie to siły ponadludzkie i wieczne, niezależne od moralności i często obojętne na los ludzi, a nawet im wrogie. Tak ich pokazywały pradawne mity.

Bogowie mogą być jednak przyjaźni i opiekuńczy, takich szuka serce człowieka. Apollo powiada do Orestesa: Nie opuszczę cię nigdy! 
Z bliska czy z oddali, / do końca strzec cię będę, chronić nie przestane (Eumenidy 65-66). Wypędzając ze swej świątyni Erynie, potępia automatyczną, chciwą krwi zemstę oraz okrucieństwa. Odwołuje się przy tym do prawa wyższego: tułacza, co błaga opieki, / odtrącić - tego lęka się i bóg, i człowiek (223-224). Nawet Erynie, piekielne mścicielki, doznają pod koniec przemiany. Trylogia mimo wszystko zmierza do sprawiedliwego i pomyślnego rozwiązania, a kończy się słowami: Zawtórujcie tej pieśni radością.

Bogowie sprzyjają bowiem sprawiedliwości. W Persach Kserkses ponosi zasłużoną karę za swą pychę, hybris. Persowie walczą w gruncie rzeczy z bogami. Ajschylos wierzy, że ocalenie Aten przed najazdami perskimi było sprawiedliwe i opatrznościowe - a w walkach tych osobiście uczestniczył, walcząc pod Maratonem, Salaminą i Platejami. Tu determinizmu nie widać, choć może dlatego, że Persowie to utwór wcześniejszy od tamtych.

W trylogii Atena na procesie Orestesa słucha obu stron; Erynie oskarżają, Apollo broni, po głosowaniu Atena ogłasza uniewinnienie (Eumenidy 751-752). Notabene lepiej jest, jeśli karę wymierza obiektywny sąd niż mściciele. Sprawiedliwość i przebaczenie przerywają łańcuch zła. Zauważmy tu pewnego rodzaju różnicę między bóstwami kosmicznymi, żywiołami, jak Zeus czy Posejdon, burza i morze, a opiekuńczymi, lokalnymi, niby niższymi w mitologicznej hierarchii, ale otwartymi na potrzeby ludzi, jak Atena i Apollo. Do takich przede wszystkim zwraca się modlitwa, jak w Siedmiu przeciw Tebom (110-117 i 127-134). Obawa przez Bogiem i zwracanie się w zamian do świętych, spotykane w chrześcijaństwie, jest zapewne refleksem tej mentalności.

Sposób pokazania mitycznego Prometeusza świadczy o poszukiwaniu jeszcze lepszej koncepcji bóstwa. Prometeusz lituje się nad ludźmi i im pomaga, cierpi za nich. Jest to jednak działanie przeciwko porządkowi świata, wręcz grzech, czyli błąd, do którego się zresztą przyznaje, godząc się z karą, choć uważa ją za zbyt okrutną (Prometeusz w okowach 275nn). Występuje tu jednak pewna analogia do Chrystusa.

Inaczej niż wiara w przeznaczenie oraz pochwały zemsty, obecne $\mathrm{w}$ tragediach motywy przebaczenia i opieki boskiej harmonizują z Ewangelią. Harmonizuje z nią też potępienie wojny domowej w Siedmiu przeciw Tebom i Fenicjankach. Temat przebaczenia spotkamy i u Eurypidesa: np. 
w Hipolicie uwieńczonym Tezeusz, każąc uśmiercić syna na skutek fałszywego oskarżenia, słyszy od niego: Zwalniam cię od winy mej śmierci (1449), a od Artemidy: Ty także możesz zyskać przebaczenie (1326).

Krytyka Zeusa w Prometeuszu jest surowa, ale wychodzi z ust jego przeciwnika, co pozwoliło autorowi tragedii przedstawić punkt widzenia bogoburcy. W późniejszych utworach Ajschylosa obraz Zeusa staje się jaśniejszy. Bywa nazywany wybawcą (gr. Soter). Odpowiada to dwóm nurtom mitologii, w jednym stwórcą i dobroczyńcą ludzi jest buntowniczy tytan Prometeusz, w drugim Zeus, widziany jako ojciec świata. Zeus stoi też za logiką odpłaty: Bo wszędy on - i tylko on! Bez niego cóż na świecie stać się może? Nie masz nic poza boża wola (Agamemnon 1485-1486).

Tak można by rzec i o Bogu jedynym, i da się tu dostrzec początki monoteizmu ${ }^{8}$, choć na razie Zeus to raczej bóg kary niż miłosierdzia. Niemniej jednak koncepcja bóstwa najwyższego z kosmicznej hierarchii staje się po części moralna i filozoficzna. Zeus wciela odwieczne prawo i czuwa nad tym, żeby winni łamania go zostali ukarani. Taka jest konsekwencja obecności bogów nieba i ziemi w świecie (widać to w przebiegu akcji Siedmiu przeciw Tebom, choć motywów Aresowych jest tam więcej).

Wyższość i obecność Zeusa jest uwypuklona w Błagalnicach, gdzie mowa o nim już w pierwszym wersie jako o przychylnym dla proszących; potem jest panem panów, najdoskonalszym, najpotężniejszym (524-527; 595-599). Wątpiącym poeta odpowiada, że wyroki Zeusa są dla ludzi niepojęte (93-94; 1049-1050). Boga człowiek dopiero szuka, nie otrzymał objawienia, prosi, ale i pyta. Zeusie, stysz! Jeśli ten imienia dźwięk upodobał sobie bóg, tak go zwę, kimkolwiek jest... (Agamemnon 158-161).

Najwyraźniej obecne są te myśli we fragmencie, którego autentyczność była kwestionowana, gdyż przechował się on u jednego z autorów chrześcijańskich, Klemensa z Aleksandrii (Kobierce 5, 14, 114), a ci nieraz cytowali urywki apokryficzne. Autentyczność cytatu potwierdził jednak papirus z tekstem Filodemosa z Gadary, pochodzący z Herkulanum, który wskazał jako źródło tragedię Heliades (Nauck, fragment 70). Czytamy: Jest Zeusem eter, Zeusem ziemia, niebo także Zeus, / Jest Zeusem wszystko i co

8 A. Zajcev, Aischylos und die monotheistischen Gedanken bei den Griechen, w: Geschichte - Tradition - Reflexion, t. 3, Fs. M. Hengel, red. H. Cancik i in., Göttingen 1996; A. Wartelle, Pensée, 546-551. 
również nad tym jest. Zmierza to ku monoteizmowi, choć z zabarwieniem panteistycznym.

\section{SOFOKLES ${ }^{9}$ : BÓSTWO MA RACJĘ}

U Sofoklesa wiara $\mathrm{w}$ przeznaczenie łączy się z pobożnością, choć sama treść jego sztuk nie jest tak mitologiczna i religijna jak u dwóch pozostałych. Bardziej interesuje go samotny człowiek i artystyczne przedstawienie jego sytuacji. Zły los jest nieuchronny, tragiczne losy Edypa wynikają z wyroczni. Co wyrzekł Apollo, musi się ziścić, choć z punktu widzenia ludzi uwikłanych w realizację wyroczni cierpią oni niezasłużenie.

Próby przezwyciężenia wyroków losu służą w ostatecznym rachunku realizacji tego, co i tak nieuniknione. U Ajschylosa fatum dotyka przede wszystkim winnych, u Sofoklesa szkodzi człowiekowi raczej złe odczytanie boskiej woli i próby sprzeciwu. Tendencja do determinizmu jest wyraźna, widać tu antycypację marksistowskiej maksymy, że wolność to uświadomiona konieczność.

Edyp nie wie wprawdzie, że zabił swego ojca Lajosa i poślubił matkę Jokastę, a więc świadomie nie zawinił, ale jednak naruszył boskie prawo, ściągnął na siebie zmazę i był gwałtowny. Błędów własnych widzieć nie chciał (Król Edyp 335), a ganiąc ślepego wieszczka, sam ślepym się okazał (por. J 9,41). Własnymi decyzjami przyczynił się do tragedii zapowiedzianej przez wyrocznię.

Za nieszczęściami Edypa stoi ostatecznie wola Apolla (Król Edyp 1360-1364). Nie prowadzi to jednak do oskarżenia bogów. Boskie prawo pozostaje wyższe i nieuniknione, a ludzkie sądy ułomne. Ostatecznie to Edyp nieświadomie wydał wyrok na samego siebie. Dramat o nim staje się poszerzoną „przypowieścią jurydyczną”: opowiadaniem, w którym sędzia sam siebie bezwiednie potępia (w Biblii 2 Sm 12,1-25).

Brak moralnej racji dla przebiegu wypadków wynika być może z pominięcia wyjaśnienia ze starszej wersji mitu. Nieszczęścia rodu Lajosa byłyby w nim karą za gwałt homoseksualny: Lajos porwał i wykorzystał chłopca

9 Brill's Companion, 411-470; por. T. Zieliński, Sofokles i jego twórczość tragiczna, Kraków 1928; R.P. Winnington-Ingram, Sophocles. An Interpretation, Cambridge 1980. 
imieniem Chryzyp, który z rozpaczy popełnił samobójstwo. Ojciec chłopca, Pelops, przeklął Lajosa. Jak w micie o rodzie Agamemnona i w starszych tekstach biblijnych, winy zbrodniarza spadają na następne pokolenia.

Choć nieszczęścia Edypa tłumaczone są przez Sofoklesa apologetycznie wolą boską, jego postać pozostaje symbolem losu człowieka w ogóle. Ludzie stoją na pozycji przegranej, a wysiłkami swymi pogarszają tylko sytuację; dociekaniami przyspieszają odkrycie własnej nędzy. Człowiek zawsze przegrywa $\mathrm{z}$ losem i tylko sobie szkodzi; taki panował pesymistyczny pogląd na świat. Pokazują to też Trachinki, osnute wokół motywu Dejaniry, która uśmierca Heraklesa, chcąc odzyskać jego miłość.

Bliższa naszemu postrzeganiu świata i prostsza, choć zarazem głęboka, jest akcja Antygony - może dlatego sztuki nadal szczególnie popularnej. Bohaterka reprezentuje w niej racje moralne i ludzką autonomię, podczas gdy Kreon jest wcieleniem woli rządzących. Ten schemat w dobie jawnych i zamaskowanych totalitaryzmów i rozdętego państwa jest nam bliski.

Owe racje moralne odpowiadają woli boskiej i boskiemu prawu, wyższemu niż ludzkie: A nie mniemałam, by ukaz twój ostry / tyle miał wagi $i$ siły w człowieku, / aby mógł łamać święte prawa boże (453-455, por. 1044). Antygona jest uparta, ale w swoim sprzeciwie kieruje się miłością. A ta wymaga czynu: słowami świadczyć miłość - to nie miłość (543); por. $1 \mathrm{~J} \mathrm{3,18.}$

Sam czyn Antygony, pogrzebanie ciała zabitego brata, którego władca Kreon chciał pozostawić na łup drapieżnikom, nie wynika z Dekalogu. Rozumiemy jednak jego wagę, skoro w wierzeniach Greków los cienia zmarłego zależał od pogrzebu, a poniewierka trupa była straszną hańbą. Zresztą i w Biblii obowiązek pogrzebu występuje, najbardziej w Księdze Tobiasza, który chowając zmarłego współbrata, ryzykuje życiem. Antygona kocha brata, rzuca więc wyzwanie Kreonowi. Oboje mają silne, nieustępliwe osobowości.

Antygona nie bierze pod uwagę winy brata, zdrady ojczyzny. Współkochać się urodziliśmy, nie wspótnienawidzieć (521). Mowa tu i o kochającym się rodzeństwie, i o ludziach w ogóle. Przypomina się kapłanka Teano, wspomniana przez Plutarcha, która na żądanie władz ateńskich, by przeklęła zdrajcę Alcybiadesa, odrzec miała, że jej zadaniem jest błogosławić, a nie wyklinać (Alcybiades 22). 
Skądinąd potrzeba zemsty była uważana za coś oczywistego: chór poucza Elektrę, by nie nienawidzić zbytnio, ale i nie przebaczać (Sofokles, Elektra 177-178, zatarte w przekładzie). Zemsta to obowiązek wobec duszy zmarłego, która się jej domaga; pilnują tego Erynie. Orestes dostaje od Apolla instrukcję co do planowanej zemsty (tamże, 35-37). Z drugiej strony zemsta rodzi zemstę, zło prowadzi do zła (580-584).

Wróćmy do Antygony. Kreon przedstawia klasyczne racje władzy. Potrzebny jest porządek, potrzebne jest karanie złoczyńców. Jednakże myli się, mówiąc: Czyż nie do władcy więc państwo należy? - gdyż raczej: marne to państwo, co li panu stuży (Antygona 737-738). Demokrata Sofokles karykaturuje apologię jedynowładztwa.

Konformizm wobec takiej władzy okazuje się słabością, co przedstawiają siostry bohaterek tragedii, Ismena w Antygonie i Chryzotemis w Elektrze. Wierność boskiemu prawu moralnemu, potwierdzenie jego słuszności i siły wymaga sprzeciwu, choćby przyszło zań zapłacić życiem. Albo żyć podle, lub zginać wspaniale (Elektra 1321). Wole piękną porażkę niż brzydkie zwycięstwo (Filoktet 95). Dla Greków piękne i wspaniałe jest zarazem dobre. Ale lęk i wątpliwości nie znikną: I podłe życie lepsze niż śmierć piękna (Eurypides, Ifigenia w Aulidzie 1252). Polskie spory o to, czy warto było walczyć i ginąć, stanowią odmianę odwiecznego dylematu.

Mimo ostrzeżeń ze strony Antygony i syna, Hajmona, Kreon przez bezduszne stosowanie zasad i pychę sprowadza nieszczęście na nich i na siebie. Nie jest do gruntu zły, po namyśle zmienia zdanie, ustępuje przed wyrocznią i koniecznością (1105nn) - ale za późno. Antygona w lochu zdążyła się powiesić, kochający ją Hajmon przebija się mieczem, jego matka się wiesza. Kreon doświadcza swojej bezsilności i upadku.

Niesprawiedliwe skazanie Jezusa na śmierć i jego wierność boskiej woli nasuwa porównanie do Antygony. Jej śmierć też jest argumentem i moralnym zwycięstwem, pewnego rodzaju męczeństwem (942-943). Mimo różnic można tu dostrzec i podobieństwo, choć niekoniecznie zamierzone. Postać Antygony, należąc do moralnego świata antyku, mogła jednak pomóc Grekom w zrozumieniu Jezusa.

Pozycja Zeusa w zachowanych dramatach Sofoklesa jest mniej istotna. Bóg kosmosu mało jest obecny wśród ludzi. Za apokryficzny uchodzi fragment zacytowany przez Klemensa z Aleksandrii (Kobierce $5,14,113)$, wzięty z drugiej ręki, od autora żydowskiego, piszącego pod 
pseudonimem Hekatajos. Istnieje tak naprawdę jeden tylko, jeden Bóg! Co niebo, ziemie też rozległa, stworzył sam. Jest jednak godne uwagi, że żydowscy i chrześcijańscy myśliciele gotowi byli uznać greckiego klasyka za monoteistę.

\section{JAK W CHRZEŚCIJAŃSTWIE: OFIARA ZA INNYCH}

Wiedzieli Grecy, że kto sprawiedliwy, ten dla bliskich żyje (Eurypides, Dzieci Heraklesa 2). Nie była im nieznana dobrowolna ofiara z życia. Odczytywano to potem jako zapowiedź chrześcijaństwa $\mathrm{z}$ jego wiarą w śmierć Jezusa za grzeszników. Kilka motywów ze świata greckiego mogło to przybliżyć.

Antygona $^{10}$ świadomie ofiaruje życie, żeby uchronić brata od pośmiertnej hańby. Ostrożnej siostrze Ismenie odpowiada: Wybrałaś życie, ja życia ofiarę (555). Złożyła ofiarę z życia $\mathrm{w}$ imię wierności zasadom i miłości dla brata, uznając śmierć za zysk, jak Sokrates i św. Paweł (Antygona 431-432; Flp 1,21; por. Ajschylos, Siedmiu przeciw Tebom 670; Platon, Obrona Sokratesa 40D).

Jeden brat, Eteokles, wychodzi walczyć z drugim, Polinejkesem, który sprowadził obcy najazd: obaj zginą, ale miasto ocaleje (Ajschylos, Siedmiu przeciw Tebom; Eurypides, Fenicjanki). W tychże Fenicjankach Menojkeus, syn Kreona, którego śmierć była według wyroczni Tejrezjasza warunkiem zwycięstwa, sam się zabił mieczem, wylewając krew na ofiarę dla sił podziemnych (1010-1012, 1090-1092). Makaria w Dzieciach Heraklesa Eurypidesa poświęca się dobrowolnie dla ratowania rodzeństwa. Dla zwycięstwa nad wrogami zagrażającymi dzieciom Heraklesa wyrocznia zażądała bowiem złożenia ofiary ludzkiej.

Takie wątki mogły inspirować pozytywną ocenę samobójstwa Razisa w Biblii (2 Mch 14,37-46), który - ścigany przez wrogów - sam sobie zadał cios mieczem, by go nie wzięto jako zakładnika. Samobójstwo mogło mieć w Grecji wymiar heroiczny, na podobieństwo męczeństwa i dobrowolnej ofiary.

${ }_{10}$ P. Pokorny, Antigone und Jesus (Opfer und Hoffnung), w: Geschichte - Tradition - Reflexion, t. 3, Fs. M. Hengel, red. H. Cancik i in., Göttingen 1996, 49-62. 
Występuje też analogia między ofiarą z Izaaka w Księdze Rodzaju $(\mathrm{Rdz} 22)$ a ofiarą i uratowaniem Ifigenii. W obu historiach występuje ofiara z dziecka, zastąpienie jej przez zwierzę, ratunek i interwencja boska. Najlepiej pasuje tu akcja Ifigenii $w$ Aulidzie Eurypidesa, gdyż we wcześniejszych wersjach mitu córka Agamemnona została zabita, jak córka Jeftego w Księdze Sędziów. Występuje tu zapewne wspólny motyw obiegowy. W ujęciu Eurypidesa (i w późniejszych opracowaniach historii o Izaaku) mowa o gotowości do ofiarowania siebie: Chcę moje ciało za moja ojczyznę / i cała grecka ziemię ofiarować (1553-1554).

Bliska chrześcijaństwu wydaje się opowieść z tragedii Eurypidesa Alkestis. Nie na darmo tę sztukę zaczął tłumaczyć Jan Kochanowski. Mojry zdradziły, że Admet ma umrzeć, chyba że ktoś go zastąpi. Szlachetna Alkestis godzi się umrzeć zamiast ukochanego męża, choć ten nie przejawiał specjalnych zalet. W greckiej baśni Herakles, gość domu, zabiera jednak Śmierci pochowaną już Alkestis i oddaje ją mężowi. Alkestis wraca do życia fizycznego, podobnie jak w Ewangelii Łazarz.

O cierpieniu Prometeusza za ludzi była już mowa. Oddanie życia za przyjaciół, zapowiedziane przez Jezusa (J 15,13), wspominali filozofowie (Arystoteles, Etyka nikomachejska 1169A; Epikur według Diogenesa Laertiosa, Żywoty 10, 121; Seneka, Listy moralne 1, 9, 10) ${ }^{11}$.

\section{EURYPIDES:12 ZAGADKA ZŁA W ŚWIECIE}

Czytelnicy i badacze Eurypidesa wahają się co do jego religijności. $\mathrm{Z}$ jednej strony wydaje się on krytykiem religii i racjonalistą, $\mathrm{z}$ drugiej

${ }^{11}$ Por. M. Reiser, Love of Enemies in the Context of Antiquity, New Testament Studies 47(2001), 411-427.

12 Zwł. R. Turasiewicz, Między pobożnością a bezbożnością. Studium religii w dramacie Eurypidesa, Prace Komisji Filologii Klasycznej 23, Kraków 1995, 23-62; por. M.R. Lefkowitz, Was Euripides an Atheist?, Studi Italiani di Filologia Classica 5(1987), 149-166; M. Morani, La religione di Euripide, Zetesis 2(1982), 5-21; H. Yunis, A New Creed: Fundamental Religious Beliefs in the Athenian Polis and Euripidean Drama, Göttingen 1988; T. Zieliński, L'Evolution religieuse d'Euripide, Revue des Etudes Grecques 36(1923), 459-479. Tło: J. Mańkowski, Mity i świat Eurypidesa (Archiwum Filologiczne 33), Wrocław 1975; J. Czerwińska, Człowiek Eurypidesa wobec zagrożenia życia, namiętnej miłości i ekstazy religijnej, Łódź 1999; R. Appleton, Euripides the Idealist, London-Toronto 1992; W. Nikolai, Euripides' Dramen mit rettendem Deus ex machina, Heidelberg 1990. 
poszukiwaczem wiary i cudu. Problem ten trudno rozwiązać, gdyż jak zwykle w dramatach nie bardzo wiemy, które głosy bohaterów wyrażają zdanie autora.

Jednakże, gdyby Eurypides uchodził za bezbożnego, nie dopuszczano by go regularnie do religijnych przecież z założenia ateńskich zawodów poetyckich. Zarzut taki wprawdzie padł, ale tylko okazjonalnie i w formie satyrycznej (u Arystofanesa). Wydaje się więc, że Eurypides bogów uznawał i nie ma sensu czynienia z niego prekursora ateizmu, natomiast stawiał pytanie o ich cechy i niepokoiło go zło w świecie. Nie zadowalał się widzeniem bóstw jako amoralnych sił natury ani też wiarą w przeznaczenie. Chciał religię uszlachetnić.

Oddawał więc głos dwóm stronom sporu: i pobożnym, i krytycznym. Okazując zainteresowanie dla sfery boskiej, nieraz kończył sztuki widomą interwencją bóstwa, które się zjawia jako deus ex machina. Nie jest to tylko baśniowy i widowiskowy happy end, jak to się często widzi.

Według Eurypidesa bogowie interesują się ludźmi, objawiają się i wkraczają w ten świat. Powtarza w finałach: $Z$ niespodzianego znalazł bóg wyjście. Albo: Nie zrozumieja śmiertelni spraw bogów, / zbawiają, kogo kochaja (Ifigenia w Aulidzie 1610-1611). Być może, jeśli uwzględnić kolejność powstawania zachowanych osiemnastu sztuk Eurypidesa, jego poglądy się zmieniały. Z początku widział bogów jako odległych od świata, potem dał wyraz pragnieniu spotkania z nimi i zyskania pomocy. Jednakże, zdaniem wielu bohaterów jego sztuk, postępowanie bogów olimpijskich budzi zgorszenie i sprzeciw. Nazywają ich złymi, bezrozumnymi i niesprawiedliwymi (Herakles 347; Ion 384-387; Andromacha 1161-1165). Złość mnie bierze na bogów (chór w Hipolicie 1146). Tak też maluje ich nieraz akcja: jako stronniczych, mściwych, okrutnych, podstępnych, małodusznych i podłych. Tacy są Afrodyta w Hipolicie uwieńczonym, Hera w Heraklesie, Dionizos w Bachantkach, choć zarazem sztuka ta świadczy o fascynacji autora dionizyjską ekstazą.

Taki obraz bogów znamy już z Homerowej Iliady. Czy Eurypides tylko go cytuje, czerpiąc z mitów materiał do tragedii? Czy pośrednio go kwestionuje słowami: Nie ma dla ludzi rzeczy cenniejszej od rozsądnego niedowierzania (Helena 1617)? Czy też, nie tracąc wiary, ma po prostu intelektualny dystans do naiwnych poglądów na bogów: Sa to tylko nędzne opowieści pieśniarzy (Herakles 1345)? 
Eurypides zna argument, że zło w świecie przeczy istnieniu bogów. Zawsze się jednak okazuje, że krytycy bogów mówią pod wpływem pychy albo cierpienia. Są subiektywni w swej niewierze. Zapominają, że złego losu nikt w świecie nie uniknie, nawet bogowie (Herakles 1314). W części sztuk w finale bóstwo przywraca ład. Człowiek wiary ufa bogom, mimo wszystko: Stużymy bogom dlatego, że sa bogami (Orestes 418).

Mimo straszliwych nieszczęść Troi stara królowa Hekabe zachowuje wiarę w opatrzność: Kimkolwiek jesteś, zagadkowy Bycie, / Zeusie, czy ładem przyrody, czy myśla / ludzką, ja czczę cię, bo zawsze bezgłośny / droga ku prawu wiedziesz ludzkie sprawy (Trojanki 885-888). Jest to wyznanie ufnej wiary, a zarazem świetne streszczenie trzech znanych już wtedy koncepcji powstania wiary w bóstwa: $\mathrm{z}$ obserwacji rozumnego porządku przyrody, z idealizacji myśli ludzkiej, z nadziei na sprawiedliwość. Skądinąd cytaty z Eurypidesa u Klemensa z Aleksandrii (Kobierce 5, 14, 114 - obok innych tragików) sugerują kojarzenie Zeusa z kosmosem: eterem, niebem, ziemią.

Ale gdzie tu leży słuszność, jacy są bogowie? Trzeba przy tym problemie pamiętać, że religia grecka nie znała samoobjawienia się Boga w formie podobnej do biblijnej, a grecka teologia była raczej filozofią religii. Dlatego, chociaż istnienie bogów nie budziło wątpliwości, rozpoznanie tajemniczej natury bóstwa było z zasady problemem. Wszystko, co boskie, niejasne dla ludzi (Oszalały Herakles 62).

Na pytanie Hekabe poeta odpowiada, wyznając wiarę w boską sprawiedliwość. Nie byłoby bogów, / gdyby bezprawie było ponad prawo (Elektra 583-584). Chór w Alkestis wzywa: Do bogów się módlmy, albowiem / bogów moc jest największa (218-219). Chór w Bachantkach zaczyna tak: Powoli kroczy bogów moc, / lecz można na niej polegać (882-883). Czyli: „Pan Bóg nierychliwy, ale sprawiedliwy”.

U Eurypidesa chodzi jednak głównie o człowieka, pokazanego mniej posągowo, a bardziej psychologicznie i egzystencjalnie. Według Arystotelesa Sofokles miał stwierdzić, że pokazuje ludzi, jakimi być powinni, Eurypides zaś takimi, jacy są (Poetyka 1460B). Do tego portretu człowieka należą bezradność wobec losu oraz wahania w wierze.

Natomiast nie ma u tragików wahań moralnych. Zło jest złem. Najmocniej chyba pokazują to Trojanki Eurypidesa, napisane podczas krwawej dla jego ojczystych Aten wojny peloponeskiej. W ślad za Home- 
rem sztuka ta odsłania okropność wojny, okrucieństwo i zdradę, cierpienia mordowanych i ich rodzin, nieszczęścia pokonanych. W tej sytuacji aktem sprawiedliwości okazuje się jednak pomsta, choć straszna, jak w finale Hekabe. Zemsta w świecie tragedii pozostaje naturalnym obowiązkiem.

Bezpośrednie związki dramatu greckiego ze światem biblijnym są, jak to można było zauważyć, drugorzędne i okazjonalne ${ }^{13}$. Powtarzają się co najwyżej pewne metafory i motywy obiegowe. Są to jednak przypadki jednostkowe. Powtarzają się też prawdy ogólne i powszechne, dlatego poznając religię tragików, z perspektywy chrześcijańskiej dostrzegamy nieraz treści znajome.

Prawdziwa więź z korzeniami chrześcijaństwa leży jednak głębiej. Tragicy greccy podjęli te same ogólnoludzkie problemy co Biblia. Wnikając w nie, ku Bogu i prawdzie posunęli się tak daleko, jak mogli. Szukali prawdziwej boskości, kwestionując ludzkie na nią poglądy. Rozpoznali nadrzędne, boskie prawo moralne, wypowiadając się przeciw złu. Dostrzegli wielkość i nędzę człowieka. Zbliżyli się do prawdy o Bogu jedynym, stwórcy i wybawcy świata.

W pewnej chwili dostrzegli jednak, że nie rozumieją: że wierząc, nie potrafią jednak wyjaśnić cierpienia, woli boskiej, losu ludzkiego. Chrześcijanin powiedzieć może, iż czekali na odpowiedź Ewangelii.

Streszczenie: Klasyczny dramat grecki nie tylko dogłębnie wniknął w naturę ludzką, lecz także miał religijną treść i kontekst. Tragicy byli w pewnym stopniu teologami. Ajschylos wybierał tematy mitologiczne. Jego logiczny umysł popchnął go ku deterministycznemu fatalizmowi; jego poczucie porządku sprzyjało stałym regułom moralnym. Apollo i Atena są bardziej osobowi i bardziej przyjaźni niż Zeus. Prometeusz działa na rzecz ludzi, ale wbrew regułom świata. Akcja dramatów Sofoklesa jest bliższa życiu ludzkiemu, ale widzianemu w świetle religii. Były one naznaczone wiarą w los, utożsamiony z boską wolą, a tym samym apologetycznie usprawiedliwiony. Wierzył on, że zasady moralne i religijne są ważniejsze od polityki. Eurypides, wbrew pewnym opiniom, był osobiście religijny, nawet jeśli stawiał śmiałe pytania dotyczące cierpienia i zła. Wypowiadał krytyki pod adresem bogów, ale także deklarował zaufanie do nich

13 Skądinąd Biblia sporo czerpie ze świata greckiego, choć raczej z motywów obiegowych i z myśli moralnej niż z literatury pięknej; por. Wojciechowski, Wpływy greckie w Biblii, Kraków 2012. Szerzej A.J. Festugière, L'Idéal. 
i przedstawiał wybawienie przychodzące od bogów, czasem w formie cudownej. Wśród motywów greckich bliskich chrześcijaństwu możemy podkreślić ofiarę za innych. Sprawiedliwość, miłość i przebaczenie są boskie. Pytania zadawane przez wielkich tragików utorowały drogę dla odpowiedzi Ewangelii.

Słowa kluczowe: Ajschylos; Sofokles; Eurypides; religia grecka; religijność dramatów greckich; dramat grecki; tragedie greckie.

Summary. Aeschylus, Sophocles, Euripides Religiousness of three Greek tragedians. The classical Greek drama not only penetrated human nature in deep, but also had a religious contents and context. Tragedians were to some extent theologians. Aeschylus chose mythological subjects. His logical mind pushed him to deterministic fatalism; his sense of order favored interest for stable ethical rules. Apollo and Athena are more personal and friendly than Zeus; Prometheus acts for humans but against the rules of the world. The plot in the Sophocles' dramas is nearer to human life, but seen in the light of religion. They were marked by the belief in fate, identified with divine will, and therefore apologetically justified. He believed that moral and religious principles are more important than politics. Euripides, contrary to some opinions, was personally religious, even if he asked bold questions concerning the suffering and evil. He voiced criticisms towards gods, but also declared trust in them and painted salvation coming from gods, often in miraculous form. Among the Greek motifs close to Christianity we may stress the sacrifice for others. Justice, love and forgiveness are divine. The questions asked by the great tragedians paved the way to the answer of the Gospel.

Keywords: Aeschylus; Sophocles; Euripides; Greek religion; religiousness of Greek dramas; Greek drama; Greek tragedies. 
